論文

\title{
農振農用地区域における非農地判断制度の導入が 農地の維持管理に及ぼす影響
}

\author{
愛媛県松山市を事例に
}

\author{
The Effects of Implementing Judgement as Non-Farmland in Area of Agricultural Land \\ on the Maintenance and Management of Farmland \\ A Case Study in Matsuyama City, Ehime Prefecture
}

\author{
藤原 千里 $^{1}$ 武山 絵美 ${ }^{*}$ \\ Chisato FUJIWARA ${ }^{1}$ Emi TAKEYAMA ${ }^{1 *}$
}

\begin{abstract}
Judgement as Non-Farmland involves the designation system of Non-Farmland applied to nonrenewable abandoned farmland (Class B) provided by the Agricultural Committee. The purpose of this study was to clarify the details on how Judgement as Non-Farmland operates at the level of municipal government in the Area of Agricultural Land and why Judgement as Non-Farmland for the area is used by farmland owners. In accordance with the above purpose, we considered the effects of implementing Judgement as Non-Farmland in Area of Agricultural Land on the maintenance and management of farmland. Our investigation revealed that management policy of Judgement as Non-Farmland differs between the national and municipal levels. This difference might arise from the perception of local government in the area that the introduction of Judgement as Non-Farmland may promote the increase of class B farmland as Area of Agricultural Land in their location. Second, we pointed out that some owners have received a Judgement as Non-Farmland designation for their farmland on mountainside slopes and among the mountains in the Area of Agricultural Land due to (1) difficulty associated with converting land with low demand for development and (2) dues required by the Land Improvement District and the burden imposed by the municipal property tax. Thus, we indicated that implementation of Judgement as Non-Farmland in the Area of Agricultural Land may lead to the following unwanted outcomes : (1) deterioration of the Land Improvement District, (2) detrimental effects on surrounding farmland, and (3) difficulties associated with consolidation.

Keywords : Area of Agricultural Land, Devastation of Farmland, Judgement as Non-Farmland, Orchard Field, Land Improvement Districts

キーワード：農用地区域，農地荒廃，非農地判断，樹園地，土地改良区
\end{abstract}

\section{1. 研究の背景と目的}

我が国の食料自給率を維持するために，農地の保全と 適切な利用を図る農用地区域（以下「青地」, 農業振興 地域のそれ以外は「白地」）の維持は重要である。しかし， 全国の青地内の「確保すべき農用地等の面積」は H26〜 $\mathrm{R} 1$ 年で 405 万 ha から 400 万 $\mathrm{ha} \mathrm{a}^{1)}$ と減少傾向である。よっ て, 現状のままでは農林水産省の定めた R12 年の目標 である 397 万 ha を達成することは厳しい。

このような青地内農地の減少理由として, 農地転用等 の青地からの除外によるものと荒廃農地の発生によるも のがある。農林水産省は $\mathrm{R} 1 \sim 12$ 年の間に, 青地内農地 のうち 7.0 万 ha が転用等により除外され， 8.3 万 ha が 荒廃農地になると見積もっており ${ }^{2}$, 後者の方が農地減
少の理由として深刻であると受け止められている。

ここで，荒廃農地には外部性問題があることが知られ る。木村 ${ }^{3}$ は, 荒廃農地の外部不経済について, 荒廃農 地が周辺農地汇(1)直接的影響（病害虫や日陰地の発生 等）と，(2)間接的影響（水路・道路における維持管理の 粗放化，通作や水管理の困難化等）を与元て拡大すると している。さらに, Izumi et al. ${ }^{4}$ は, 傾斜地の樹園地で 発生する荒廃農地が地滑りの起点となるなど，土砂災害 のリスクを高めることを報告しており，武山ら 廃農地は周辺での獣害の温床になることを報告している。 すなわち，外部性問題に鑑みても，荒廃農地の発生防止 と解消は喫緊の課題である。

このような荒廃農地に係る研究には, 例えば荒廃農地 の発生原因と拡大化の過程を検討した木村 ${ }^{6}$ や耕作放棄

1愛媛大学大学院農学研究科

'Graduate School of Agriculture, Ehime University

Corresponding Author* : takeyama@agr.ehime-u.ac.jp 
地の位置的特徵や農家の特徵から耕作放棄化防止の要件 を考察した九鬼ら ${ }^{7)}$ がある。また, 青地の保全に係る研 究には, 不耕作化の発生要因を発生位置と営農状況や営 農意向から求め, 青地保全のための計画的課題を検討し た藍澤ら ${ }^{8)}$ がある。

一方，近年青地の荒廃農地に係る制度変更があった。 具体的には, H24 年度から荒廃農地を再生利用可能な A 分類と再生利用困難と見込まれる $\mathrm{B}$ 分類に区分するこ ととなり, $\mathrm{H} 26$ 年度から農業委員会が B 分類に対して 非農地としての判断（以下，「非農地判断」）を速やかに 行うこととなった。しかし, このような制度変更が青地 内農地の維持管理に及ぼす影響を検討した研究は無い。 $\mathrm{H} 21$ 年度の農地法改正による遊休農地の再生等への影響 を検討している緒方 ${ }^{9)}$ や, 長野市の非農地判断の取り組 みから遊休農地対策の実施体制と荒廃農地への対応を明 らかにしている堀部 ${ }^{10)}$ があるものの, 青地内での制度変 更に着目している研究はなく, 青地において荒廃農地の 取り扱いに係る制度変更が実際の現場でどのように運用 されているかは不明瞭な点が多い。

そこで本研究は愛媛県松山市を対象として, 第 1 に, 青地における非農地判断が実際の地方自治体レベルでど のように運用されているのかを明らかにする。第 2 に, 青地における非農地判断の仕組みが, 農地所有者によっ て選択される背景を明らかにする。以上より，青地にお ける非農地判断という新たな仕組みの導入が, 地域にお ける農地の維持管理に及ぼす影響を考察する。

\section{2. 研究の概要}

\section{1 研究対象地域の概要}

松山市は, 愛媛県のほぼ中央にある松山平野に位置し, $\mathrm{R} 2$ 年現在の人口は 51 万人である ${ }^{11)} 。$

$\mathrm{H} 30$ 年のデータ注1) によると, 市域面積 42,940haのうち, 都市計画区域は $21,447 \mathrm{ha}$, そのうち市街化調整区域は 14,419ha を占める。さらに市街化調整区域全体と都市計 画区域外にわたり，農業振興地域 25,635 ha が設定され ており, その $20 \%$ を青地が占める。青地内農地のうち, 樹園地は $84 \%$ を占め, そのうち $93 \%$ は基盤整備注 2 未実 施である。また, $\mathrm{H} 13$ 年度のデータによると, 青地内の 樹園地のうち傾斜度 8 度以上のものは $80 \%$ を占め, 傾 斜地での柑橘栽培が盛んである ${ }^{12)}$ 。

松山市は，荒廃農地に係る制度変更を受け，H27 年か ら荒廃農地を A 分類と B 分類に分け始め, H29 年から 青地における非農地判断の運用を始めている。

\section{2 調査の方法}

第 1 に, 青地における非農地判断が実際の地方自治体 レベルでどのように運用されているのかを明らかにする ため，まず，Table 1-NO.1〜 5の非農地判断および非 農地判断の前段階となる荒廃農地の判定状況に係る法律 と通知を整理し, 国における制度変更の経緯や運用上の 条件と手続きを把握した。次に, 松山市農水振興課 （R1.10.4，12.9），松山市農業委員会事務局（R1.12.9）, 松山市資産税課（R2.4.15） への聞き取り調查を行い, 松山市の青地における制度導入の経緯や運用上の条件と 手続きの実態を把握した。また，比較として，松山市に おける白地の荒廃農地に係る制度運用上の条件や手続き を把握するため，松山市農業委員会事務局への聞き取り 調査および Table 2 の要領の整理を行った。

第 2 に，青地における非農地判断の仕組みが，農地所 有者によって選択される背景を明らかにするため, Table 3-NO.1, 2 の分析を行い, 非農地判断を受けた農地 の面積・場所を整理した。次に, 非農地判断を申請した 農家の属性やその理由を把握するために, 申請者リスト の入手を試みたが，個人情報保護の観点から了承されな かった。そこで, 本研究では渋谷 ${ }^{13)}$ の例に習い, 非農地 判断を申請した農家の属性やその理由について松山市農 水振興課に聞き取り調査を行うことで代替した。また， 比較として, 白地における荒廃農地と非農地判断を受け た農地の面積を把握するため, Table 3-NO.1, 3 の分 析を行った。最後に, 土地改良区の非農地判断に対する 見解等を把握するため, 松山市農水振興課に対し, 非農 地判断の申請者が属する土地改良区の特定を試みたが, 個人情報保護の観点から了承されなかった。そこで, 本 研究では, 松山市において組合員数最大の $\mathrm{C}$ 土地改良 区に対する聞き取り調査（R1.12.5）を行った。C土地 改良区はS32 年に行われた国営事業の後に設立された 広域土地改良区であり, 松山市内の地区単位の土地改良 区と連携していることから，C土地改良区の見解は松山 市の土地改良区全体を代表するものと判断した。

\section{3、国における制度変更および運用}

\section{1 国における制度変更の経緯}

H19 年度に農林水産省は, 「農地政策の展開方向につ いて」年)において「現状を的確に把握した上で，それぞ れの状況に応じたきめ細やかな対策を実施することによ り，5年後を目途に耕作放棄地の解消を目指す」とした。 この目標を達成するために, 農林水産省は H20 年度, Table 1-NO.1 の通知により, 荒廃農地の荒廃状況を一 筆毎に把握する耕作放棄地全体調査を始め ${ }^{15}$, 耕作放棄 
Table 1 荒廃農地の判定に係る法律と通知, およびその発行元 The law and notice related to judgment of devastated agricultural land and the publishers who provided them

\begin{tabular}{|c|c|c|c|}
\hline NO. & 発行元 & $\begin{array}{l}\text { 制定・ } \\
\text { 通知日 }\end{array}$ & 法律 - 通知名 \\
\hline 1 & $\begin{array}{l}\text { 農林水産省 } \\
\text { 農村振興局長 }\end{array}$ & H20.4.15 & $\begin{array}{l}\text { 荒廃農地の発生・解消状況に関する調 } \\
\text { 査要領 }\end{array}$ \\
\hline 2 & $\begin{array}{l}\text { （農林水産省） } \\
\text { 経営局長 }\end{array}$ & H20.4.15 & $\begin{array}{l}\text { 耕作放棄地に係る農地法第 } 2 \text { 条第 } 1 \text { 項 } \\
\text { の「農地」に該当するか否かの判断基 } \\
\text { 準等について }\end{array}$ \\
\hline 3 & $\begin{array}{l}\text { 農林水産省 } \\
\text { 経営局長・ } \\
\text { 農村振興局長 }\end{array}$ & $\mathrm{H} 21.12 .11$ & $\begin{array}{l}\text { 「農地法の運用について」の制定につ } \\
\text { いて }\end{array}$ \\
\hline 4 & $\begin{array}{l}\text { 農林水産省 } \\
\text { 構造改善局長 }\end{array}$ & H12.4.1 & $\begin{array}{l}\text { 農業振興地域制度に関するガイドライ } \\
\text { ン }\end{array}$ \\
\hline 5 & 農林水産省 & S44.7.1 & $\begin{array}{l}\text { 農業振興地域の整備に関する法律（第 } \\
15 \text { 条の } 2 \text { ) }\end{array}$ \\
\hline
\end{tabular}

Table 2 非農地証明取扱要領の条件 The condition in guidelines of Non-Farmland proofs

\begin{tabular}{c|l}
\hline \hline NO. & \multicolumn{1}{|c}{ 非農地証明の対象とする土地 } \\
\hline 1 & $\begin{array}{l}\text { 農地法が施行された日（昭和 } 27 \text { 年 } 10 \text { 月 } 21 \text { 日）前から非農地で } \\
\text { あった土地 }\end{array}$ \\
\hline 2 & 自然災害による被災地で農地への復旧が困難な土地 \\
\hline 3 & \begin{tabular}{l} 
昭和 27 年 10 月 21 日以降農地であった土地のうち, 耕作不適, \\
耕作不便などやむを得ない事情によって 20 年以上にわたり耕作 \\
放棄されたため自然潰廃し, 雑木林が繁茂した土地で, 農地へ \\
の復旧が著しく困難なもの \\
\hline 4
\end{tabular} $\begin{array}{l}\text { その他, 農地転用許可を要しない事案など, 適法に転用が行わ } \\
\text { れた土地 }\end{array}$ \\
\hline
\end{tabular}

Table 3 非農地判断の分析に用いた資料とその発行元 The data used for analysis of Judgement as Non-Farmland and their publishers who provided them

\begin{tabular}{|c|c|c|c|}
\hline NO. & 発行元 & $\begin{array}{c}\text { データ } \\
\text { 記載期間 }\end{array}$ & 資料名 \\
\hline 1 & $\begin{array}{l}\text { 松山市 } \\
\text { 農水振興課 }\end{array}$ & $\mathrm{H} 22 \sim 30$ 年 & $\begin{array}{l}\text { 確保すべき農用地等の面積の目標の } \\
\text { 達成状況 }\end{array}$ \\
\hline 2 & $\begin{array}{l}\text { 松山市 } \\
\text { 農水振興課 }\end{array}$ & $\mathrm{H} 29 \sim \mathrm{R} 2$ 年 & $\begin{array}{l}\text { 松山市農用地区域における非農地判 } \\
\text { 断一覧 }\end{array}$ \\
\hline 3 & $\begin{array}{l}\text { 松山市 } \\
\text { 農業委員会 } \\
\text { 事務局 }\end{array}$ & $\mathrm{H} 21 \sim 30$ 年度 & 農業委員会事務処理実績報告 \\
\hline
\end{tabular}

地を土地の現況により，「緑（簡易な作業で営農再開 可)」, 「黄 (基盤整備により営農再開可)」,「赤 (森林化 • 原野化しているもの)」に区分するとともに，「赤」の耕 作放棄地に対し Table 1-NO.2 の通知に基づき, 農地・ 非農地の判断を行うこととした ${ }^{16)}$ 。

また, H25 年の農地法改正では, 農業委員会の手続き を大幅に改善・簡素化することにより, 遊休農地の発生 防止と速やかな解消を図ることとされた。これに先立ち, 農林水産省は H24 年度, Table 1-NO.1 の通知を改正し, 荒廃農地を「A 分類 (再生利用可能なもの)」と「 類（再生利用困難と見込まれるもの）」に分けることと していた。なお,この通知を改正した際，「耕作放棄地 全体調査」の名称が「荒廃調査の発生・解消状況に関す
る調査」へ変更された ${ }^{15)}$ 。さらに $\mathrm{H} 26$ 年の農地法改正 では, 遊休農地対策が強化され， $\mathrm{A}$ 分類は農地としての 活用を図る措置が設けられ， B 分類は速やかに非農地化 して整理することとされた。この改正にあたり， Table 1-NO.3 も改正され, 農業委員会は利用状況調査の結果, $\mathrm{B}$ 分類があった場合は, 原則として利用状況調査を行っ た年内に, 非農地判断を行うことが適当とされた

すなわち, 遊休農地の発生防止と速やかな解消を図る ために，荒廃農地を A 分類と B 分類に区分し, B 分類 に対して非農地判断を行うよう，制度が変更されてきた 流れであったと言える。

青地で非農地判断された土地は, Table 1-NO.4によ り青地に残置することが適当とされているとともに, Table 1-NO.5により開発行為が規制されている。ただ し, 青地で非農地判断された土地を青地に残置するかの 判断は, 各市町村に委ねられている。

\section{2 国における制度運用上の条件}

Table 1-NO.1 において B 分類に区分する条件は，荒 廃農地のうち, 「森林の様相を呈しているなど, 農地に 復元するための物理的な条件整備が著しく困難なもの」 又は「周囲の状況からみて, その土地を農地として復元 しても継続して利用することができないと見込まれるも の」と定義されている。B 分類に区分された荒廃農地は, 非農地判断を受けることができる（Table 1-NO.3 参照）。

\section{3 国における制度運用上の手続き}

農地の所有者が非農地判断を申請すると, 農業委員会 は利用状況調査又は荒廃農地の発生・解消状況に関する 調査等を行う。その結果, 当該農地が $\mathrm{B}$ 分類に該当す れば, 総会又は部会の議決により非農地と判断され, 所 有者および都道府県, 市町村, 法務局等の関係機関に対 してその旨が通知されるとともに, 農地台帳が整理され る（以上 Table 1-NO.3より）。

\section{4.松山市における制度変更および運用}

松山市農水振興課への聞き取り調査をもとに，以下に 松山市における制度の導入経緯・運用条件・手続きを整 理する。

\section{1 松山市における制度導入の経緯}

$\mathrm{H} 27$ 年から荒廃農地を A 分類と B 分類に分ける制度 を導入した理由は，「長年にわたる耕作放棄による荒廃 化の進展や集団的な荒廃化が進んでいる状況に対応する ため」とのことであった。 
このうち青地の B 分類に対し松山市では, H29 年か ら非農地判断を導入している。そのきっかけは, 農地の 耕作が困難になった農地所有者へ, 事業者が太陽光発電 を提案し, その事業者の代行者が松山市農水振興課に 「荒廃農地を非農地にしてもらえないだろうか」という 相談をしたことであった ${ }^{18)}$ 。その相談を受けて行われた 愛媛県と松山市の話し合いにおいて,「Table 1-NO.3の 法律に準拠すれば，青地であっても非農地判断を行うこ とが可能なのではないか」という結論に至ったとのこと である。具体的には「所有者には現況に合わせて登記を 変える権利があるにも拘わらず, 『青地なので農地でな ければいけない』という農業政策上の制限により, 固定 資産税や賦課金を支払う義務を課して良いのかと考えた ときに，青地に残置し開発を規制するという条件付きで あれば，個人単位の登記変更を認めてもいいのではない か」という結論に至ったとのことである。

なお，白地に非農地判断を導入した経緯は，前述の青 地とは異なる。白地では, Table 1-NO.3の改正以前から, Table 2 の要領に基づき, 非農地判断が行われている。 具体的には, 農業委員会により法律に基づかないサービ スとして, 農地所有者からの申請農地に対し, 非農地判 断を行っている。白地における非農地判断の導入経緯を 松山市農業委員会事務局に尋ねたところ,「いつからど のような経緯で導入されたのかは分からないが, S38 年 度には既に非農地判断の実績があったことを確認できた。 松山市で現在運用している要領（Table 2）になったのは, $\mathrm{H} 26$ 年である。とのことであった。

\section{2 松山市における制度運用上の条件}

$\mathrm{B}$ 分類の条件は「3.2 国における制度運用上の条件」 の通りである。松山市農水振興課によると「樹園地の荒 廃は山林と区別するのが難しい。」とのことであったが, 松山市農業委員会事務局によると「国のB 分類の基準 以外に判断基準は設けていない。日ごろの農地パトロー ルで養った農業委員会の目で復旧可能か否かを見極めて いる。とのことであった。松山市では, Table 1-NO.3 の法律に基づき,「農地が $\mathrm{B}$ 分類であること」のみを基 準に青地での非農地判断を行っている。

これに対し松山市における白地での非農地判断の条件 は, Table 1-NO.3 の改正以降も変わらず Table 2 の要 領に基づいている。特に荒廃農地に係る非農地判断 （NO.3）は「20年以上にわたり耕作放棄された」ことが 条件とされており, 具体的な年数が明記されていること が青地と異なる点である。

松山市農水振興課によると, このような非農地判断の 青地と白地における条件の違いは, H29 年の制度導入に
ついての話し合いでは「議論にならなかった」とのこと であったが, 条件の違いをどのように捉えているかを尋 ねたところ, 担当者個人の見解として「青地の条件を白 地に統一した方がいいのではないか」と話された。

\section{3 松山市における制度運用上の手続き}

松山市農水振興課によると, 青地における非農地判断 の存在を知っているのは, 実際に非農地判断を行ったこ とがある人か手続きに関わっている人（行政書士・司法 書士等）〈らいであり, 農地所有者から非農地判断につ いて問い合わせを受けることはほぼ無いとのことであっ た。農地所有者から荒廃農地について「農地を何十年も 耕作しておらず荒れてしまったが, 後継者もいない。確 認してみたところ農地が青地に入っていると分かったが, このまま荒廃農地として置いておくしか手は無いのか。」 といった相談を受け, 農地復旧や後継者育成等の様々な 事業を勧めた後, 最終手段として非農地判断を紹介する とのことであった。荒廃農地の相談頻度は「月に数回」, 非農地判断の紹介に至る頻度は「3 か月に 1 回程度」と のことであった。

非農地判断の紹介を受けた青地の農地所有者は, 松山 市農水振興課に非農地判断の申請を行う。申請を受け, 松山市農水振興課は対象地の現地確認を行う。その後, 農業委員会に非農地判断を依頼し, 農業委員会による現 地調査にて B 分類と認められれば, 毎月 1 回開催され る総会に諮られる。総会にて非農地として判断されれば, 農業委員会は農地所有者に対象地が非農地である旨の通 知を送るとともに, 対象地を農地台帳から削除する。

また, 松山市資産税課によると, 農業委員会から対象 地が非農地判断されたという報告を受け，その土地の現 況を現地調査で確認し, 課税地目を決定しているとのこ とであった。

5.松山市における制度運用下での荒廃農地の現状

\section{1 件数および面積}

まず, 農業振興地域における耕地面積と荒廃農地面積 の内訳（H30 年）を Fig.1 に示す。松山市の青地におけ る B 分類は, 耕地面積と荒廃農地面積の合計 5,101ha の うち 400ha（7.8\%）であった。一方，白地におけるB 分類は, 合計 $3,777 \mathrm{ha}$ のち $260 \mathrm{ha}(7.0 \%)$ であった。よっ て, 青地における B 分類の割合は白地より $0.8 \%$ 高かっ た。また, 青地における $\mathrm{B}$ 分類の割合を比較すると, 松山市は全国平均（1.9\%）より5.9\%高かった。

次に, 松山市の非農地判断を受けた件数・面積の推移 を Fig.2 に示す。青地の非農地判断は導入開始の H29 年 


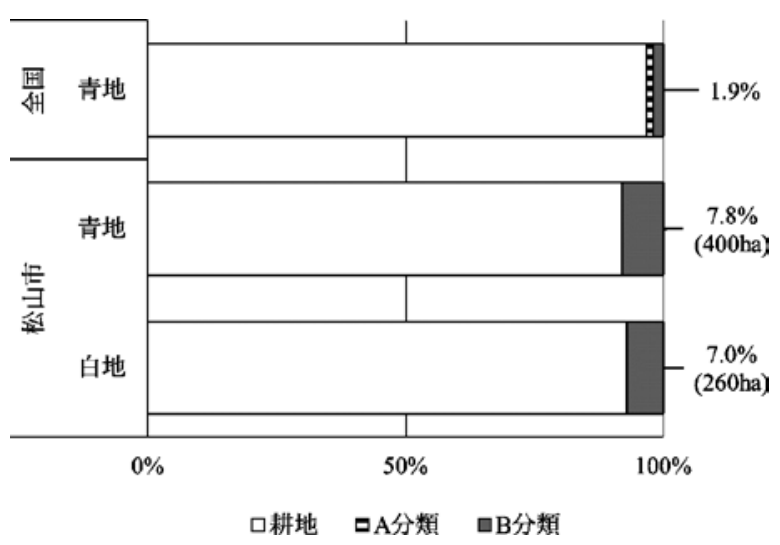

Fig.1 農業振興地域の耕地面積々荒廃農地面積の内訳

The area percentage of cultivated fields and abandoned farmland in the agricultural promotion area

出所）松山市の值は Table 3-NO.1, 全国平均の青地内耕地の値は農林 水産省 ${ }^{1)}$, 全国平均の青地内 $\mathrm{A} \cdot \mathrm{B}$ 分類の值は農林水産省 ${ }^{19)}$ より作成

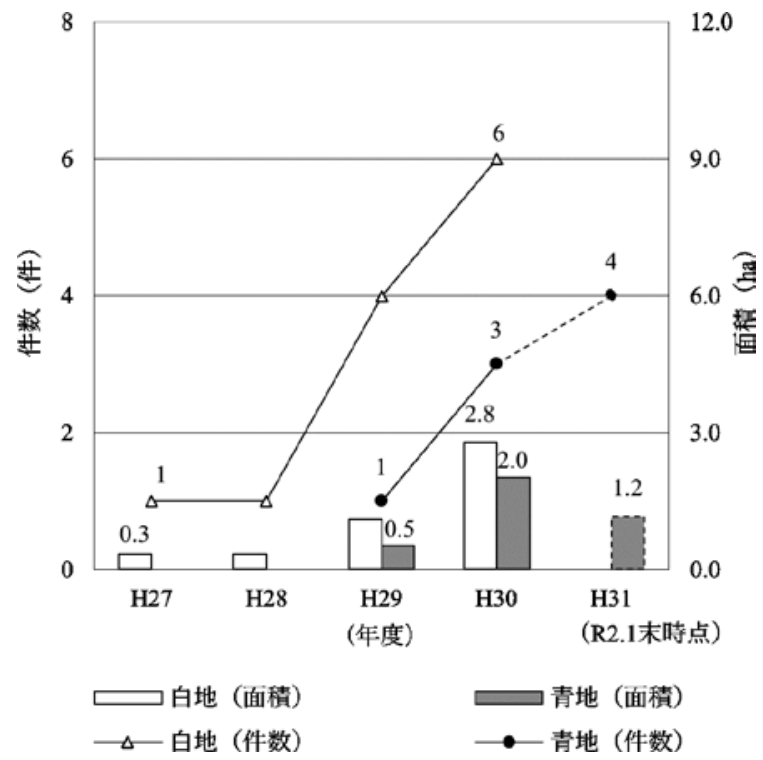

Fig.2 非農地判断を受けた件数・面積の推移

The transition of the farmland numbers and area judged as Non-Farmland

注） $\mathrm{H} 31$ 年度の值は, R2 年 1 月末時点のものである。 R2 年 2 3 月分 の非農地判断を受けた件数・面積の值は不明であるので, $\mathrm{H} 31$ 年度のグ ラフを点線で表記している。

出所）Table 3-NO.2, 3 上り作成

度では 1 件， $0.5 \mathrm{ha}$ であったが，H30 年度では 3 件， $2.0 \mathrm{ha}$ であり増加していた。なお，白地における荒廃農地に係 る非農地判断は H27～30 年度にかけて，件数は 1 件か ら 6 件, 面積は 0.3 ha から 2.8 ha と, ともに増加していた。

\section{2 場所}

まず，Table 3-NO.2 を用いて H29〜R2 年に青地の非 農地判断を受けた農地全 3.7 ha が立地する地域の農業地 域類型を調べたところ，中間農業地域が $1.8 \mathrm{ha}$ ，都市的 地域が $1.1 \mathrm{ha}$, 平地農業地域が $0.7 \mathrm{ha}$, 農業地域類型を特
定できなかった地域が $0.2 \mathrm{ha}$ であり, 半数が中間農業地 域であった 注3)。また，青地における非農地判断を受け た農地面積のうち, 登記地目が畑のものは $82 \%$, 田の ものは $18 \%$ であった。ここで，ゼンリン電子住宅地図 デジタウン愛媛県松山市を用いて，これらの全 30 筆の 農地の地番をプロットした。ただし, 農地の地番を住宅 地図で確定することはできなかったため, 最も近い地番 の位置にプロットした。その結果, 非農地判断を受けた 農地の場所は 8 か所にまとめられた。次に, その 8 か所 を Google map にプロットし, 航空写真で確認した。そ の結果 Fig.3 のように, 非農地判断を受けた農地全てが 山際および山中に立地していた。

\section{3 申請者の属性}

松山市農水振興課に H29〜R1 年度末の申請書類を確 認していただいた。それによれば，青地における非農地 判断の申請者は 13 人であり, そのうち 11 人が 60 歳以上, 7 人が申請農地以外にも耕作農地を所有していた。しか し, 松山市農水振興課への聞き取り調査によれば,「耕 作農地を所有している 7 人の大半は，実際にはほとんど 作っていないとおっしゃっていたと記憶している。」と

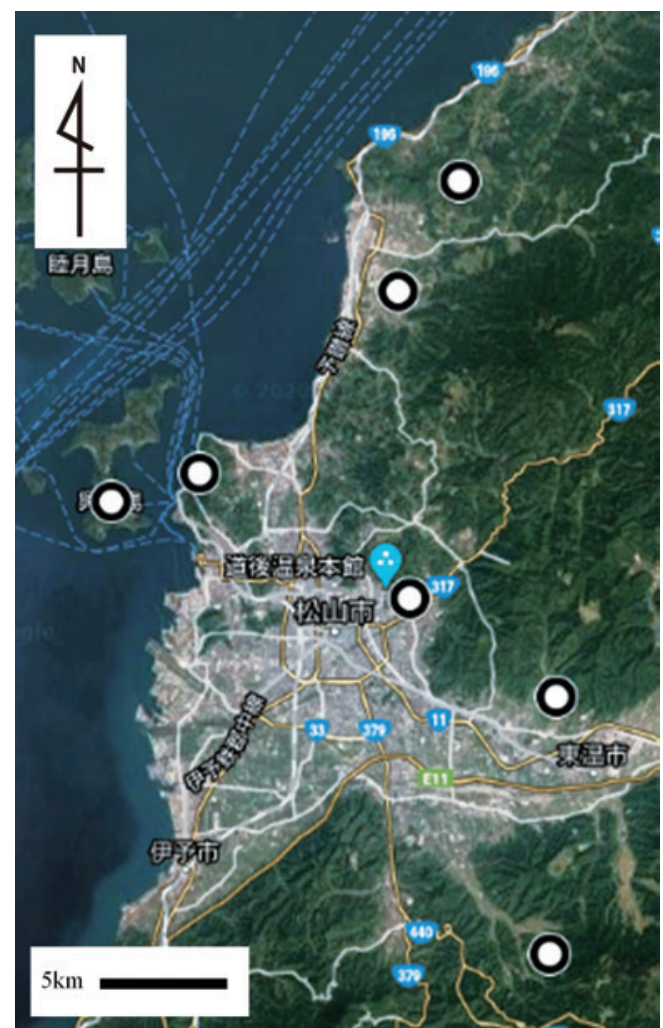

Fig.3 非農地判断を受けた農地の場所（航空写真） The location of farmland judged as Non-Farmland (an aerial photograph)

注）Google Map で作成。8 か所のうち 2 か所は同じ地区内のためプロッ トが重なる。

出所）Table 3-NO.2 より作成 
のことであった。

\section{4 申請理由}

松山市農水振興課への聞き取り調査によれば，青地に おける非農地判断の申請理由として代表的なものは $2 つ$ あるとのことであった。1つ目は，「賦課金の免除」で あった。非農地判断を受けた農地は, 土地改良区から地 区除外されると考えられる。よって, 農地所有者は土地 改良区に対する賦課金を払う必要がなくなる。2つ目は, 「固定資産税の軽減」であった。松山市資産税課による と,「固定資産税は基本的に, 課税地目が農地より山林 の場合の方が安い」とのことであった。よって，農地所 有者は非農地判断を受け, 松山市資産税課により課税地 目が山林と判断されれば，固定資産税を軽減することが できる。

なお，松山市農水振興課への聞き取り調査によれば, 「非農地判断により 0.7 ha を非農地化した農地所有者の 場合，その理由は相続の際の財産整理であった。子世代 に賦課金や比較的高い固定資産税がかからないようにす る方法を土地改良区に相談したところ，非農地判断を受 ければ賦課金の免除が可能であると言われ，非農地判断 の申請を決めた。とのことであった。

そこで，松山市で組合員数最大の $\mathrm{C}$ 土地改良区に聞 き取り調査を行ったところ，「今までに非農地判断によ る地区除外の相談を受けたことはない」とのことであっ たが，今後非農地判断を受けた組合員から地区除外につ いて相談された場合は,「地区除外の方向で進める」と のことであった。

\section{6. 考察}

\section{1 地方自治体レベルにおける非農地判断の運用実態}

国は，遊休農地の発生防止と速やかな解消を図るため に, 荒廃農地 $\mathrm{A} \cdot \mathrm{B}$ 分類の区分及び $\mathrm{B}$ 分類の非農地化 を進めることとしていた。一方，松山市は青地における 非農地判断を最終手段として紹介する等, 非農地判断を 極力避けたい方針であり，国の考光方との間に差がみら れた。

このように松山市が非農地判断に消極的な背景として, 非農地判断の仕組みが荒廃農地の再生を妨げる可能性が ある点を指摘できる。非農地判断の存在は, 傾斜地にあ る未整備の青地・樹園地のような, 条件は悪いが規制は 強い農地の所有者にとって荒廃化を肯定するものとなり， 再生意欲の低下につながる可能性がある。
6.2 非農地判断が農地所有者に選択される背景

松山市の青地には B 分類が比較的多かった。この背 景として，松山市の青地内農地には樹園地が多く含まれ ており，このような樹園地の傾斜地率と未整備率は高い ことから，傾斜地にある未整備の樹園地が多いことが推 察される。

また，青地における非農地判断の制度は，山際および 山中の農地で利用されていた。この背景を検討するため に山際および山中における $\mathrm{B}$ 分類の条件に着目する。 まず，前提条件として，B 分類は再生利用困難な荒廃農 地であることから，農地所有者による農地としての活用 は難しい。そこで農地を農地以外とする方法として農地 転用と非農地判断があるが，山際および山中における開 発需要は低いため農地転用による活用は厳しい。よって, 山際および山中に立地する B 分類の所有者は，B 分類 を農地以外に活用することも出来ずに所有し続け，土地 の維持費を払い続けなければならない。これに対し非農 地判断を受けると，「賦課金の免除」や「固定資産税の 軽減」が期待できる。以上より，青地における非農地判 断が山際および山中の農地の所有者によって選択される 背景として, 山際および山中の農地における開発需要が 低く，金銭的負担の軽減が非農地判断を利用するメリッ トになっていることを指摘できる。

\section{3 非農地判断の導入が青地内農地の維持管理に及ぼす 影響}

非農地判断の導入が青地内農地の維持管理に及ぼす影 響を検討するために， $\mathrm{B}$ 分類が非農地判断を受ける場合 と受けない場合を比較する。まず，B 分類が非農地判断 を受ける場合，土地改良区から地区除外され，賦課金を 支払う必要がなくなると考えられる。非農地判断を受け た土地が土地改良区から地区除外されると，賦課金収入 が減少する。このような土地改良区の経営悪化は，賦課 金単価の上昇や土地改良施設の維持管理の困難化，ひい ては土地改良区の解散につながり, 農家の営農状況の悪 化とさらなる B 分類の増加を招く可能性がある。また, 本研究の通り, 非農地判断の申請理由が農地以外の用途 としての利用ではなく, 金銭的負担の軽減である場合, 非農地判断を受けた後の土地は全く管理されない可能性 が高い。荒廃農地の外部性問題に鑑みると，非農地判断 を受けた後の土地が地域農業に及ぼす悪影響は大きい。 さらに, 本研究では青地に未整備の農地が多く含まれて いることが分かった。非農地判断を受けた土地が青地内 に点在すると, これを含む地域の今後の固場整備の検討 が困難になり，ひいては地域全体の農業の活性化を阻む 要因となり得る。 
一方, $\mathrm{B}$ 分類が非農地判断を受けない場合, $\mathrm{B}$ 分類の 所有者は土地改良区の賦課金を支払い続け，金銭的負担 を抱える。その代わり，農地再生事業や戒場整備事業を 検討したり，新たな担い手を探したりする可能性が残る。 実際に，武山ら ${ }^{20)}$ は，管理不足の樹園地が $72 \%$ を占め る地域において，固場整備を実施した例を報告している。

\section{7。結論}

本研究では，青地における非農地判断が，実際の地方 自治体レベルでどのように運用されているのかを明らか にした。また，青地における非農地判断の仕組みが，農 地所有者によって選択される背景を明らかにした。以上 より，青地における非農地判断という新たな仕組みの導 入が，地域における農地の維持管理に及ぼす影響を考察 した。

その結果，第 1 に，国レベルと現場レベルの非農地判 断の運用方針には違いがあり，その背景には，非農地判 断の導入は青地での B 分類の増加を促進するのではな いかという現場の懸念があることを指摘した。第 2 に, 青地における非農地判断の仕組みが選択される背景とし て，開発需要が低い山際および山中に立地する農地の所 有者にとって，土地の維持費を軽減できるというメリッ トがあることを指摘した。最後に，青地における非農地 判断の導入は, 土地改良区の経営悪化や周辺農地への悪 影響, 圑場整備事業の困難化につながる危険性があるこ とを指摘した。

今後の農地制度には, 非農地判断を受ける条件の厳格 化や土地利用計画に基づく非農地化, 非農地判断を受け た後の土地の維持管理方法を具体的に検討することが求 められる。農地を適切に保全しうる農地制度や適切な非 農地判断制度のあり方について, 他国の農地制度等との 比較研究から明らかにすることを今後の課題としたい。

\section{謝辞}

本研究の遂行にあたり，松山市農水振興課，同農業委員会事 務局，同資産税課，および $\mathrm{C}$ 土地改良区の皆様より，多大なる ご協力を賜った。ここに記して深謝申し上げる。なお，本研究 は科研費（17H03890）および愛媛大学相橘イノベーションセ ンター・宇和島市受託研究（令和 2 年度）の成果を含む。

\section{注勫}

注 1 ) Table 3-NO.1 のデータより

注 2 ）松山市農水振興課によると「基盤整備」の定義は,「大 規模な事業を指す。土地改良事業，かんがい排水事業，戋 場整備事業を含む。とのことであった。なお，未整備の 農地が青地に多い理由を確認したところ「相橘が儲けてい た時代に，条件の悪い山を切り開いて樹園地とし，青地を 初めて設定する際にそのような樹園地の多くを補助事業が 使えるようにするために青地に入れた可能性がある。」と
のことであった。

注 3 ) 小数点第 2 位を四捨五入している関係で, 青地の非農地 判断を受けた農地全 3.7 ha と農業地域類型別の面積の合計 （3.8ha）が一致しない。

\section{引用文献}

1 ）農林水産省（2020）（参照 2020.11.20）：農用地等の確保等 に関する基本指針，（オンライン），入手先 $<\mathrm{https://www.}$ maff.go.jp/j/nousin/noukei/totiriyo/t_sinko/sinko_04.html>

2 ）農林水産省（2020）（参照 2020.11.19）：令和 2 年度第 5 回 配付資料，（オンライン），入手先<https://www.maff.go.jp/j/ council/seisaku/nousin/bukai/r02 1119/siryou.html>

3 ) 木村和弘（1993）：山間急傾斜地水田の荒廃化と全村圃場 整備計画，農業土木学会誌，61 (5)，405 410.

4 ) Izumi, T., Takeyama, E., Sato, Y. and Kobayashi, N. (2021): Damage to Agricultural Infrastructure in Ehime Prefecture Resulting from the Heavy Rain Event of July 2018-Focusing on Damage to Orchard Fields and Irrigation Tanks-, Journal of Rainwater Catchment Systems, 26 (2), 15-25.

5 ) 武山絵美・九鬼康彰（2013）: 獣害対策改善への合意形成 に資する集落診断手法の検討一和歌山県古座川町潤野地区一 の適用結果から，農業農村工学会論文集，81 (1)，17-23.

6 ）木村和弘（1981）：山村農地の荒廃化とその対応，農業土 木学会誌, 49(4), 309-316.

7 ）九鬼康彰・高橋強（1997）：都市近郊農業集落における耕 作放棄の実態とその防止策一都市近郊農地の耕作放棄防止に 関する研究（II），農業土木学会論文集，191，33-45.

8 ）藍澤宏・井上健介・野間正純（1993）: 大都市近郊におけ る農振農用地内の農用地の保全に関する研究, 日本建築学会 計画系論文報告集，447，79-88.

9 ）緒方賢一（2013）：2009 年農地法改正における遊休農地対 策規定とその適用の現段階，高知論叢，106，75-103.

10）堀部篤（2015）: 中山間地域における遊休農地対策の実施 体制と荒廃した農地への対応一長野市農業委員会における農 地利用調査および非農地判断の取り組みから, 農村研究, 120, 27-38.

11）松山市役所（2020）（参照 2020.9.11）：松山市の位置・気 候・地形・人口，松山市公式ホームページ PC サイト，（オ ンライン), 入手先 $<$ https://www.city.matsuyama.ehime.jp/shisei/matsuyama/iti.html $>$

12）中国四国農政局農村計画部農村振興課（2006）：中国四国 の農地の現況一第 4 次土地利用基盤整備基本調査. 愛媛県, 171.

13）渋谷往男（2011）：企業の農業参入における撤退要因と農 地管理についての考察, 農業経営研究, 49(1), 81-86.

14）農林水産省（2007）（参照 2020.9.4）：農地政策の展開方向 について，(オンライン)，入手先<https://www.maff.go.jp/j/ press/keiei/koukai/pdf/071106-01.pdf $>$

15）国立研究開発法人 農業・食品産業技術総合研究機構 農村 工学研究部門（2017）（参照 2021.2.16）：Google Earth を用い た荒廃農地の可視化マニュアル，(オンライン), 入手先 $<$ http://www.naro.affrc.go.jp/publicity_report/publication/files/kohainochi-kashika_manual_3.pdf>

16）農林水産省（2010）（参照 2021.2.16）：耕作放棄地全体調 査の実施について，(オンライン），入手先＜https://www.pref. yamaguchi.lg.jp/cms/a17200/houkichi/index/apd1_2 20100212090 94333.pdf>

17）福島県農村振興課 一般社団法人福島県農業会議 (2020) (参 照 2021.2.16）：再生困難農地の非農地判断と利活用に向けた 話し合いの進め方マニュアル，(オンライン), 入手先 $<$ http://www.fnkaigi.com/20030263 view.pdf $>$

18）松山市役所（2020）（参照2020.9.10）：農業委員会総会等 の議事録を公表します，松山市公式ホームページ PC サイト， 
(オンライン), 入手先 $<$ https://www.city.matsuyama.ehime.jp/ kurashi/sangyo/noringyo/nochi/nougyou_gijiroku.files/163soukai. pdf $>$

19）農林水産省（2019）（参照 2019.7.7）：荒廃農地の発生防止・ 解消等, (オンライン), 入手先 $<$ https://www.maff.go.jp/j/nou $\sin /$ tikei/houkiti/index.html>
20）武山絵美・西久保依里佳（2021）: 傾斜地の樹園地圃場整 備に向けた合意形成促進要因一愛媛県松山市の柑橘園地にお ける農地中間管理機構関連農地整備事業を対象として, 原著 論文，農業農村工学会論文集，312，掲載決定済.

（2020.12.13 受理，2021.3.14 採用） 